\title{
THE RELEVANCE OF INDUSTRIAL PSYCHOLOGY AS A PROFESSION AND DISCIPLINE IN SOUTH AFRICA
}

\author{
STEPHEN D RENECLE \\ Stephen Renecle \& Associates
}

\begin{abstract}
In exploring whether or not Industrial Psychology is relevant, it is proposed that while the discipline has an important impact on the South African economy, the profession in this country has little relevance. The view is offered that it is more important that the discipline of Industrial Psychology remains relevant over time than for the profession to become relevant. Proposals are put forward in terms of how to maintain the relevance of Industrial Psychology as a discipline in a changing organisational environment.
\end{abstract}

\section{OPSOMMING}

Daar word voorgestel dat terwyl Bedryfsielkunde as dissipline ' $n$ belangrike rol in die Suid-Afrikaanse ekonomie speel, die professie in ons land irrelevant is. Die standpunt word gestel dat dit belangriker is dat Bedryfsielkunde as dissipline tersaaklik bly, as wat dit is vir die professie om op datum te kom. Voorstelle word gemaak oor hoe om die tersaaklikheid van die dissipline te handhaaf in ' $n$ veranderende organisatoriese omgewing.

Currently a key question with respect to Industrial Psychology pertains to its relevancy during these times of rapid and fundamental change, and more specifically its relevancy as a discipline and profession. The purpose of this article is to address this question. It is argued that while the discipline has an important impact on the South African economy, the profession in this country has little relevance in practice. The article proceeds by, firstly, indicating the relevance of Industrial Psychology as a discipline; secondly, by arguing that Industrial Psychology as a profession is irrelevant to everyday practice; and, thirdly, by offering some proposals on how to maintain the relevance of Industrial Psychology as a discipline in a changing organizational environment.

\section{INDUSTRIAL PSYCHOLOGY AS A RELEVANT DISCIPLINE}

Unequivocally, Industrial Psychology as a relevant discipline or more specifically, the application of the principles of human behaviour in the workplace has, and will continue to have, a central impact on the human condition. Principles arising from Industrial Psychology are interwoven in management practice. The terminology from the discipline is part and parcel of the South African manager's daily nomenclature. In South Africa thousands of university, technicon and college graduates take the principles they have learned in their studies of human resources management and apply them over time in organisations, either directly, or in terms of the outlook (or philosophy) which frames their approach to the working world.

Understandably therefore, over time organisations have adapted to the needs of people so that productivity, quality of work life and self-actualization are promoted. Trends that demonstrate this include: flatter organisational structures, the devolution of power, fragmentation of organisations into smaller entities, shared ownership and the incentivisation for achievement.

Moreover, evidence abounds that organisational effectiveness is promoted through the application of the principles of Industrial Psychology (see for example, Khumalo, 1999). In addition, it is unthinkable that we will succeed in a world economy built on intellectual capital (Handy, 1995; Bennis, 1998) and creativity (Coy, 2000) without the input of the discipline we call Industrial or Organisational Psychology. Without any doubt Industrial Psychology as a discipline plays an important role in the South African economy.

Requests for copies should be addressed to: SD Renecle, Stephen Renecle \& Associates, PO Box 2040, Halfway House, 1685

\section{INDUSTRIAL PSYCHOLOGY AS AN IRRELEVANT PROFESSION}

While the place of the discipline in enhancing the world of work is certain, the same cannot be said for Industrial Psychology as a profession in South Africa. If a profession is an occupation requiring specific, specialized education (Fowler \& Fowler, 1966), then Industrial Psychology in South Africa is clearly not a profession. If the occupation of the Industrial Psychologist is applying the discipline as discussed earlier in this paper, then the vast majority of those practicing Industrial Psychology are not Industrial Psychologists, as only a very small percentage of those practicing Industrial Psychology are indeed registered as such (Renecle \& Crafford, 1990). The difference between the Industrial Psychologist and the many others working in the field of people management and performance, is that the functioning of the former is regulated, whereas the latter are free from so-called professional regulation. This is particularly relevant in areas such as advertising and promotion.

Furthermore, the profession as an umbrella is becoming increasingly irrelevant for practicing Industrial Psychologists. The profession, for example, remains regulated by the Health Professions Council of South Africa, whereas Industrial Psychology has as much to do with health professions as does auditing or street sweeping. Few practicing Industrial Psychologists are involved in the profession's structures and even fewer in the regulatory bodies. An illustration of this is the new professional practice framework, which has no impact on the "professional practice" of the Industrial Psychologist. It is only relevant in terms of who may call themselves an Industrial Psychologist and who may not. Similarly, many of the activities undertaken on behalf of psychology are focused on the broader profession and have no bearing on Industrial Psychology. Looking back to the 1960's and beyond, it has periodically been argued that psychology tends to be inwardly focused, thus limiting its impact as a profession (Dunnette, 1966).

Fortunately, those who are registered as Industrial Psychologists (and many Psychologists registered in other categories who are practicing as Industrial Psychologists), continue to apply the principles of the discipline in South African organisations with arguably impressive results. Many of these professionals have de-registered with the regulatory body as they feel that they derive no benefit for the annual fee. More still, it is believed, remain registered simply to be allowed to retain the title of Industrial Psychologist.

The question is, is the irrelevance of the profession relevant, 
particularly if the discipline is applied effectively? Probably to a lesser extent in the eyes of the recipients of industrial psychological services, but certainly so in the eyes of the Industrial Psychologist. A more accessible and prominent professional identity would encourage organisations to seek out the services of registered Industrial Psychologists in preference to less qualified providers.

A variety of strategies could be applied to achieve this end (see Renecle \& Crafford, 1990), but essential approaches would include: the removal of unnecessary regulatory restrictions; alignment with workplace organizations, rather than the health professions in order to more appropriately position and promote the profession; and marketing of the profession and its members in general.

\section{CHALLENGES FACED BY INDUSTRIAL PSYCHOLOGY AS A DISCIPLINE TO ENSURE ITS RELEVANCY}

Perhaps the more important question to ask is what challenges are faced by Industrial Psychology as a discipline, to ensure its continued relevance? Organisational and societal changes are currently giving rise to new sets of needs, to which the discipline will need to respond appropriately. Moreover, for the discipline to have an optimal impact, it will be necessary to predict the needs arising from environmental change.

Some of the most important demands that the discipline will need to respond to include the following:

- organisational fragmentation, characterised by a dramatic trend towards decentralization, outsourcing, networked organisations comprising interrelated independent satellites and small service related organisations (see, for example, Porter, 1998, Kelly, 1995, Byrne, 2000).

- the so called "zero sum game" where capital is measured in intellectual terms rather than in financial terms (Thurow, 1998). This is economy where the fundamental basis of competition is founded on creativity and the generation of ideas (Coy, 2000), demanding that organisations perpetually reinvent themselves (Handy, 1998) and let go of existing approaches, where required, even when they appear to be working (Prahalad, 1998).

- in specifically South African terms, a society that demands competencies far beyond existing levels, to cope with organisational needs, both private and public.

To appropriately respond to these demands, given that they are in a perpetual state of dynamic flux, Industrial Psychology will have to be need-focused and alert. Drawing on fundamental principles of human behaviour, the practitioner will need to adapt strategy and invent approaches and methodologies to strive towards everchanging needs based outcomes on an ongoing basis. Some of the more important strategic thrusts for the discipline would appear to be the following:

- fundamental to meeting current social and economic demands is to empower people and develop competencies in order to both create and respond to opportunities. This strategy should focus on development thrusts in two primary areas, namely: the development of intellectual capital, in particular thinking skills, logic and creativity, as well as operational competencies; and the development of emotional capital with particular reference to self-esteem, commitment, courage, drive, passion and trust.

- with the fragmentation of organisations and the proliferation of networks of small service based organisations forming the backbone of the world economy, Industrial Psychology will need to focus progressively more on service delivery at the level of the individual or small group. This is particularly so with the trend towards self-managed development and diverse, unique, individual development needs.

- in order to have a meaningful impact on satisfying organisational needs, the Industrial Psychologist will need to structure service delivery in terms of outcomes rather than practices. Professions have traditionally focused on method, rather than outcome (Feyerabend, 1976). This is particularly true in the field of human resources management (Ulrich, 1998). The restriction inherent in this paradigm is that the Industrial Psychologist is not constantly harnessing all creative resources towards addressing specific needs and achieving specific outcomes, but is instead selecting and implementing more or less predetermined courses of action and implementing them. An outcomes based approach may, for example, focus on achieving: aligned vision; commitment to strategy; enhanced competency levels; and organisation-wide trust. Traditional methods based approaches would, for example, typically focus on: facilitating strategic planning sessions; presenting training programmes; recruiting and selecting staff and facilitating organisational change interventions.

While traditional methods may in many cases be appropriate to address specific needs, it is clear that in many instances they limit the impact that the Industrial Psychologist may have.

\section{CONCLUSION}

The Industrial Psychologist, or at least Industrial Psychology as a discipline rather than as a profession, will need to play a leading role in the new economy, not as a profession. As noted by Senge (1998), technology itself does not bring about change and computers merely do what people do anyway, just faster. It is the hearts and minds of people that will determine whether or not the twenty first century will be a better place to live in. As Handy (1998) puts it:

"For years, corporate chairmen have been talking about their people as their primary assets. It's time they woke up to the fact that it's actually true, because their only hope for future security lies in the brains of those people ( $p 30) . "$

Whether Industrial Psychology in its professional cloak can make this contribution is severely doubted. Industrial Psychology as a discipline however, if it remains relevant by facing up to the emerging challenges, will make an invaluable contribution.

\section{REFERENCES}

Bennis, W.G. (1998). Becoming a leader of leaders. In R Gibson (Ed.). Rethinking the future. London: Nicholas Brealey.

Byrne, J. A. (2000). Management by web. Businessweek Online, August, 28.

Coy, P. (2000). The creative economy. Businessweek Online, August, 28.

Dunnette, M.D. (1966). Fads, fashions, and folderol in psychology. American Psychologist, 21(4), 343-352.

Feyerabend, P.K. (1976). Defense of anarchy. In M.H. Marx \& F.E. Goodson (Eds.), Theories in contemporary psychology. New York: Macmillan.

Fowler, F.G. \& Fowler, H.W. (1966). The pocket Oxford dictionary. London: Oxford University Press.

Handy, C. (1995). The age of unreason. London: Random House.

Handy, C. (1998). Finding sense in uncertainty. In R. Gibson (Ed.). Rethinking the Future. London: Nicholas Brealey.

Kelly, K. (1995). Out of control: The new biology of machines, social systems and the economic world. New York: Addison-Wesley.

Khumalo, R. (1999). The Management of human resources in successful companies - an African context. Journal of Industrial Psychology, 25(1) 1-6.

Porter, M. E. (1998). Creating tomorrow's advantages. In R. Gibson (Ed.). Rethinking the Future. London: Nicholas Brealey.

Prahalad, C.K. (1998). Strategies for growth. In R. Gibson (Ed.). Rethinking the Future. London: Nicholas Brealey.

Renecle, S.D. \& Crafford, D. (1990). Organisational psychologists: a dead consulting society? Paper presented to the eighth Annual Congress of the Psychological Association of South Africa.

Senge, P. (1998). Through the eye of the needle. In R. Gibson (Ed.). Rethinking the Future. London: Nicholas Brealey.

Thurow, L.C. (1998). Changing the nature of capitalism. In R. Gibson (Ed.). Rethinking the Future. London: Nicholas Brealey. 
Ulrich, D. (1998). A New Mandate for Human Resources. Harvard Business Review, 376(1), 124-134. 